\title{
EFFECTS OF FERTILIZATION ON LEAF NUTRIENTS CONTENT AND YIELD OF IRRIGATED POTATOES
}

\section{Hamdi Badawi*, Ashraf Swidan* and Nourden Balg*}

\section{ABSTRACT}

This study was conducted through a field experiments in the Libyan Arab Jamahiriya, Tripoly at Almarazeeg area south east Tripoly International Airport. In a field trials the fertilization of potato variety Sponta, with different rates and times of fertilizer N P K application and their effects on leaf nutrients content and potato yield was examined. Leaf samples were collected from the, field experiment three times during the grown season, namely at 45, 60, and 75 days after emergence. Leaf samples were analyzed for $\mathrm{N}, \mathrm{K}, \mathrm{Ca}$ and $\mathrm{Mg}$. The results showed that leaf- $N$ content within the deficiency levels late in the season (75 days from emergence) in low yielding treatments, where $K$ was low in high yielding treatments, but adequate, late in the season. Leaf-Ca content seems to be adequate. Where $M g$ at the deficiency level throw all treatments and plant growth stages.Heavy $N$ and $P$ fertilization gave the highest potato yield obtained (up to40.oo t/ha).

\section{INTRODUCTION}

Trigated potatoes in Libya are usually grown on sandy loams or loamy sands soil low in organic matter, these soil lack ability to supply nutrients for crop growth. Growing potatoes for high yield and quality needs a balanced fertilization management without which growth and development of the crop are poor and both yield and quality of tubers are diminished. Potato demands high level of soil nutrients due to relative poorly developed and shallow root system in relation to yield Rhue and Robertson. (1981) stated that, the direct $P$ deficiency symptoms are not usually observed in potatoes, even when deficiency limits growth and markedly reduces yields. Only after $\mathrm{P}$ deficiencies have become severe the crop will began to develop visible signs of $\mathrm{P}$ stress, at first by stunted dark green leaves. Later, the edges of the youngest leaves may begin to fold downwards.

* High Technical Institute of Agriculture-Elgeran.- Tropli- Libyan 
Roberts and Mc Dole. (1985) studied the potassium has a crucial role in the metabolic such as the movement of sugars from leaves to tubers and the transformation of sugar into potato starch, and maintenance of tissue water relations Kidder and Hochmuth. (1989) investigated the Potatoes require a large amount of soil $\mathrm{K}$ than any other nutrient. Tubers remove 1.5 times as much potassium as nitrogen and 4-5 times the amount of phosphate. Sharma and Arora (1989) but the ability of the plant to grow and take up nutrients from the soil cannot be predicted accurately from the soil analysis alone, since soil analysis does not take in account other factors affecting plant growth rather than the soil. Plant tissue analysis could give an efficient mean of monitoring plant nutrient status and also would aid calibrate fertilizer requirements of the crop, potential deficiencies can sometimes be detected early enough to be corrected during the growing season.Grewal and Sharma (1991) The need for higher doses than the presently recommended, my stem from the intensive potato-based cropping systems which may led to a decline in available K due to removal in excess of applied K. Badawi (1992) stated that It's generally recognized that soil analysis alone is not always a satisfactory guide to reflect the nutritional status of the crops. Recommendations based on soil analysis alone, assume that plant roots extract nutrients from the soil in a manner comparable to chemical extractants. Perrenoud, (1993) showed that a crop yielding 37t/ha removes $113 \mathrm{~kg} \mathrm{~N} / \mathrm{ha}, 45 \mathrm{~kg}_{2} \mathrm{O}_{5}$ and $196 \mathrm{~kg} \mathrm{~K} \mathrm{~K}_{2} \mathrm{O}$ per hectare. At high yields, nutrients removal in tubers is very high, the potatoes crop is a heavy remover of soil- $\mathrm{K}$ and is the nutrient taken up in the greatest quantity.Thus, potato is regarded as indicator crop for $\mathrm{K}$ availability because of the high K requirement Westermann, et. al.(1994) reported that many researchers supports that a $\mathrm{N}$ fertilization between 150-200 $\mathrm{kg} / \mathrm{ha}$ is adequate for optimal potato yield Phosphorus plays an essential role in plant growth, root development, accelerates and enhances maturity, which directly impacts yield and potatoes quality. Marschner (1995) evaluated the potassium deficiencies reduce the yield, size, and the quality of the potato crop. A lack of adequate soil $\mathrm{K}$ is also associated with low specific gravity in potatoes. For most sandy soils the recommended $\mathrm{K}$ fertilization rate is $150 \mathrm{~kg} \mathrm{k}_{2} \mathrm{O} / \mathrm{ha}$ Fagera and 
Jones.(1997) noted that a crop yielding $79 \mathrm{t} / \mathrm{ha}, \mathrm{N}, \mathrm{P}$ and $\mathrm{k}$ accumulate in tubers was $282 \mathrm{~kg} \mathrm{~N} / \mathrm{ha}, 92 \mathrm{~kg} / \mathrm{ha}_{2} \mathrm{O}_{5}$ and $384 \mathrm{~kg} \mathrm{~K}$ O/ha. Singh and Trehan.(1998) found that, the high rate of dry matter production results in large amounts of nutrients removed by unit time, which generally most of the soils are not able to supply. Hence, fertilizers application becomes essential. High yield can only obtained through the application of optimal NPK doses in balanced proportion. Hassan, (1999) studied the potatoes tubers contain $2.68 \mathrm{~kg} \mathrm{~N} / \mathrm{t}, 0.62 \mathrm{~kg} \mathrm{P} / \mathrm{t}$ and $4.67 \mathrm{~kg} \mathrm{~K} / \mathrm{t}$, but these levels affected with yield obtained and $\mathrm{N}$ fertilization, increasing $\mathrm{N}$ fertilization increase crop yield and $\mathrm{N}$ content of tubers, and decrease the $\mathrm{P}$ and $\mathrm{K}$ content of tubers markedly. Proper $\mathrm{N}$ fertilization is one of the most important factors affecting growing potatoes for high yield of excellent quality. Adequate supply of $\mathrm{P}$ throughout the growing season is required. During the early growth stages, $\mathrm{P}$ stimulates the development of a vigorous root system. Plant demand for $\mathrm{P}$ peaks at tuber set and early bulking, and then slows during later bulking. As well known $\mathrm{P}$ generally moves very little in soil, it is important to place the $\mathrm{P}$ within the root zone to stimulate the early-season growth required for high yields. Sharma, et. al. (1999) state that fertilizer doses for potatoes grown in 300\% cropping intensity should be raised by $50 \%$ of the recommended one in order to get more profit". Soil analysis and nutritional diagnosis may be adopted to assess the efficient use of fertilizer. Soil test have been used generally to determine plant nutrients sufficiency or deficiency levels The objectives of this study were to determine nutrients content and yield of potatoes with special reference to the general fertilization practices for irrigated potatoes in the area, to have a primary knowledge of expected nutritional problems that may face potatoes production.

\section{MATERIALS AND METHODS}

The data in this study came from a field experiment carried out in the Libyan Arab Jamahiriya, Tripoly at Almarazeeg area south west Tripoly International Airport. In a field trials the fertilization of potatoes Solanum TuberosumL. Variety Sponta was studied. The fertilization treatments designed as the most potato farmers in the area treated their crops (the most three farmer's fertilization practice in the area) in addition to the recommended fertilization rate. The experiment was set up in a complete 
randomized blocks design with four replications. Analyses of variance were used for the evaluation of the yields.

\section{Treatments combinations as below:}

Treatment A: $30 \mathrm{~m}^{3} /$ ha of chicken manure added pre-planting. Fertilizer $12: 24: 12$, broadcasted in two equal doses at the rate of $300 \mathrm{~kg} / \mathrm{ha} 15$ and 45 days from emergence. Urea $46 \% \mathrm{~N}$, broadcasted in two equal doses at the rate of $50 \mathrm{~kg} / \mathrm{ha} 21$ days and 52 days from emergence.

(The recommended dose of potatoes fertilization)

Treatment B: $30 \mathrm{~m}^{3} /$ ha product of Tripoly waste factory added preplanting. Fertilizer 12-24-12, broadcasted pre-planting at the rate of 1000 $\mathrm{kg} / \mathrm{ha}$. Fertilizer $18-46$ at the rate of $1750 \mathrm{~kg} / \mathrm{ha}$, broadcasted in three doses: $500 \mathrm{~kg} / \mathrm{ha} 15$ days, and $500 \mathrm{~kg} / \mathrm{ha} 30$ days and $750 \mathrm{~kg} / \mathrm{ha} 45$ days from emergence.

Treatment C: $30 \mathrm{~m}^{3} /$ ha of chicken manure added pre-planting. Fertilizer $18-46$ at the rate of $800 \mathrm{~kg} / \mathrm{ha}$, broadcasted in two equal doses at the rate of $400 \mathrm{~kg} / \mathrm{ha} 20$ days and 45 days from emergence. Urea $46 \% \mathrm{~N}$ at the rate of $100 \mathrm{~kg} / \mathrm{ha}$, broadcasted in two equal doses at the rate of $50 \mathrm{~kg} / \mathrm{ha}$ 27 days and 52 days from emergence.

Treatment D: $50 \mathrm{~m}^{3} / \mathrm{ha}$ of chicken manure added pre-planting. Fertilizer $18-46$ at the rate of $2100 \mathrm{~kg} / \mathrm{ha}$, broadcasted in two equal doses at the rate of $1050 \mathrm{~kg} / \mathrm{ha} 15$ days and 30 days from emergence.

The potato variety Sponta was sown during the second week of September with a seed rate of $3 \mathrm{t} / \mathrm{ha}$ potato tubers $(30 \mathrm{~cm}$ apart and $60 \mathrm{~cm}$ between ridges).Soil sample (compost) collected at a depth of $0-30 \mathrm{~cm}$ and a sample of irrigation water. Recommended procedures were used in determining the physical and chemical properties of the soil (22) (Table 1). and the irrigation water (Table 2).

Leaf samples were collected randomly three times during the growing season at 45, 60, and 75 days from emergence from each treatment. The youngest fully expanded mature leaves (The 4th and 5th from the growing tip) of 25 plants per treatment were collected. Samples were first washed with tap water several times and then rinsed in distilled water; oven dried at about $70^{\circ} \mathrm{C}$ for 72 hours, grounded and kept in plastic bags for analysis. Since the mineral elements content were expressed on dry matter basis, a subsample of about 10 grams were dried at about $105^{\circ} \mathrm{C}$ 
over night and then cooled on desiccators. Nitrogen was then determined by micro-Kjeldahl method Pearson, (1970). Potassium by flame photometry. Calcium and magnesium by titrate with versenate (E.D.T.A). For technical reasons we could not able to analyzed for more nutrients.

Table 1: The physical and chemical properties of the experimental site

\begin{tabular}{|c|c|c|c|c|c|c|c|c|c|c|c|}
\hline $\begin{array}{l}\text { Dept } \\
\mathrm{h} \mathrm{cm}\end{array}$ & $\begin{array}{l}\mathrm{pH} \\
1: 1\end{array}$ & $\begin{array}{l}\text { EC } \\
\mathrm{ds} / \mathrm{m}\end{array}$ & $\begin{array}{l}\text { San } \\
\text { d \% }\end{array}$ & $\begin{array}{l}\text { Silt } \\
\%\end{array}$ & $\begin{array}{l}\text { Clay } \\
\%\end{array}$ & $\begin{array}{l}\text { Solu } \\
\mathrm{Ca}^{++}\end{array}$ & $\begin{array}{l}\text { cation } \\
\mathrm{Mg}^{++}\end{array}$ & $\begin{array}{r}\text { Ind ar } \\
\mathrm{Na}^{+}\end{array}$ & $\begin{array}{r}\text { ons } \mathbf{m} \\
\mathbf{K}^{+}\end{array}$ & $\begin{array}{l}\mathrm{q} / \mathrm{L} \\
\mathrm{HCO}^{-}\end{array}$ & $\mathrm{Cl}^{-}$ \\
\hline $0-30$ & 7.7 & 0.32 & 88.9 & 10.0 & 1.10 & 1.4 & 1.2 & 0.2 & 0.4 & 1.0 & 1.0 \\
\hline
\end{tabular}

Table2:analysis of irrigation water

\begin{tabular}{|c|c|c|c|c|c|c|c|c|c|}
\hline \multirow[t]{2}{*}{ pH } & \multirow{2}{*}{$\begin{array}{l}\text { EC } \\
\text { ds } / m\end{array}$} & \multicolumn{8}{|c|}{ Soluble cations and anions meq/L } \\
\hline & & $\mathbf{C a}^{++}$ & $\mathrm{Mg}^{++}$ & $\mathrm{Na}^{+}$ & $\mathbf{K}^{+}$ & HCO & $\mathrm{Cl}^{-}$ & $\mathrm{SO}_{4}^{-}$ & $\mathrm{NO}_{4}$ \\
\hline 7.2 & 1.7 & 6.1 & 5.1 & 5.9 & 0.4 & 2.9 & 8.6 & 5.9 & 0.15 \\
\hline
\end{tabular}

\section{RESULTS AND DISCUSSION}

Table 3 shows the effect of treatments on leaf-N content. Leaf content decreased with plant age in all treatments, these results agreed with previous studies Hassan, (1999). In high yielding treatments(D and B), the content did not decreased below $3 \%$ where in low yielding ones $\mathrm{A}$ and $\mathrm{C}$ the content is $1.2 \%, 1.3$ respectively, which is below the deficiency level of $2 \%$. There is a correlation between leaf- $\mathrm{N}$ content and potato yields.

Table 3: effect of treatments on leaf- $N$ content during the growing $\operatorname{season}(\%$ on D.M.B)

\begin{tabular}{|c|c|c|c|}
\hline \multirow{2}{*}{ Treatment } & \multicolumn{3}{|c|}{ Plant age: days from emergence } \\
\cline { 2 - 4 } & 45 & 60 & 75 \\
\hline A & 3.80 & 2.80 & 1.30 \\
\hline B & 4.00 & 3.60 & 3.01 \\
\hline C & 3.60 & 2.80 & 1.20 \\
\hline D & 4.20 & 4.08 & 3.25 \\
\hline
\end{tabular}

Results of leaf-K content as affected by treatments are presented in Table 4. Early in the season (45 and 60 days from emergence) the leaf-K content seems to be high throughout all treatments (24.6) and tended to decrease late in the season (75 days from emergence), in high yielding 
treatments ( $\mathrm{B}$ and $\mathrm{D}$ ) which may be trance located to tubers. In low yielding, the reverse situation was true, that accumulation of $\mathrm{K}$ occurred where no more tubers to move.

Table 4: Effects of treatments on leaf-K content during the growing season (\% on D.M.B)

\begin{tabular}{|c|c|c|c|}
\hline \multirow{2}{*}{ Treatment } & \multicolumn{3}{|c|}{ Plant age: days from emergence } \\
\cline { 2 - 4 } & 45 & 60 & 75 \\
\hline A & 5.00 & 4.25 & 5.30 \\
\hline B & 5.87 & 4.87 & 3.90 \\
\hline C & 4.00 & 4.10 & 5.90 \\
\hline D & 5.25 & 5.26 & 3.37 \\
\hline
\end{tabular}

Data of Table 5 show the effect of treatments on leaf-Ca content. We noted that $\mathrm{Ca}$ content increased with time in treatment $\mathrm{B}$ and $\mathrm{C}$. However it's seemed to be adequate all over treatments and sampling dates (24). Symptoms of calcium deficiency are not as well defined as those for magnesium. In most situations, tubers are small and deformed while the foliage appears normal. High tuber calcium has been associated with improved storage ability which is not investigated at these present studies. Further investigations especially on tuber-ca content were badly needed.The leaf-Mg content as affected by treatments was presented in Table 6. Magnesium content seems to be limiting, (4) stated that to have vigorous vegetative growth, $\mathrm{Mg}$ concentration on dry bases should be $0.3-0.4 \%$ in potatoes leaves which is far away from the present finding. (24) defined a concentration above $0.2 \%$ leaf-Mg to be sufficient. We observed that $\mathrm{Mg}$ content was almost not affected by plant age.

Table 5: effects of treatments on leaf-Ca content during the growing season (\%on D.M.B)

\begin{tabular}{|c|c|c|c|}
\hline \multirow{2}{*}{ Treatment } & \multicolumn{3}{|c|}{ Plant age: days from emergence } \\
\cline { 2 - 4 } & 45 & 60 & 75 \\
\hline A & 0.70 & 1.20 & 0.80 \\
\hline B & 0.4 & 1.04 & 1.16 \\
\hline C & 1.20 & 1.40 & 1.60 \\
\hline D & 0.60 & 0.40 & 0.80 \\
\hline
\end{tabular}


Table 6: effects of treatments on leaf-Mg content during the growing season (\%on D.M.B)

\begin{tabular}{|c|c|c|c|}
\hline \multirow{2}{*}{ Treatment } & \multicolumn{3}{|c|}{ Plant age: days from emergence } \\
\cline { 2 - 4 } & 45 & 60 & 75 \\
\hline A & 0.14 & 0.14 & 0.12 \\
\hline B & 0.13 & 0.13 & 0.16 \\
\hline C & 0.03 & 0.18 & 0.13 \\
\hline D & 0.09 & 0.14 & 0.12 \\
\hline
\end{tabular}

The potato yields as affected by treatments were presented in Table 7 potato tubers ( $\mathrm{t} / \mathrm{ha})$. Analysis of variance for yields evaluation was showed in Table 8. The average yield of selected farmer's fertilization practice (B, C, and D) was presented in Table 9. Were No farmer agreed to have the recommended fertilization rate (Treatment A). There was a highly significant (at $\mathrm{p}<0.01$ ) difference between fertilization treatments, however treatments B and D gave the highest yield obtained. Similar results of high potato yields (40 t/ha) were noted in Libya by (26); but as the same situation the $\mathrm{N}$ fertilization rate used were more than $370 \mathrm{~kg} / \mathrm{ha}$. Nitrogen rate below $200 \mathrm{~kg} / \mathrm{ha}$ (Treatment A and C) seems to decreased potato yields markedly in such soils, and believed to be the most limiting nutrients.

Table 7: Effects of different fertilization treatments on potatoes yield

\begin{tabular}{|c|l|l|l|l|l|}
\hline Treatment & \multicolumn{1}{|c|}{$\mathbf{R}_{\mathbf{1}}$} & $\mathbf{R}_{\mathbf{2}}$ & \multicolumn{1}{|c|}{$\mathbf{R}_{\mathbf{3}}$} & \multicolumn{1}{|c|}{$\mathbf{R}_{\mathbf{4}}$} & Average \\
\hline A & $\mathbf{9 . 4 0}$ & $\mathbf{1 1 . 1 5}$ & $\mathbf{8 . 9 0}$ & $\mathbf{8 . 5 0}$ & $\mathbf{9 . 4 9}_{\mathbf{c}}$ \\
\hline B & $\mathbf{4 0 . 0 0}$ & $\mathbf{3 9 . 5 0}$ & $\mathbf{3 8 . 0 0}$ & $\mathbf{4 2 . 5 0}$ & $\mathbf{4 0 . 0 0}_{\mathbf{a}}$ \\
\hline C & $\mathbf{1 1 . 2 5}$ & $\mathbf{1 0 . 3 0}$ & $\mathbf{1 2 . 1 5}$ & $\mathbf{1 1 . 0 0}$ & $\mathbf{1 1 . 1 8}_{\mathbf{c}}$ \\
\hline D & $\mathbf{3 8 . 0 0}$ & $\mathbf{3 7 . 2 5}$ & $\mathbf{3 9 . 5 0}$ & $\mathbf{3 6 . 8 5}$ & $\mathbf{3 7 . 9 0 _ { b }}$ \\
\hline
\end{tabular}

$$
\text { L.s.d } \mathrm{d}_{(\mathrm{p}<0.01)}=2.01 \quad \text { C.V. }=5.30 \%
$$

Table 8: Analysis of variances (A.N.O.V.A)

\begin{tabular}{|l|l|l|l|l|l|}
\hline S.O.V & d.f & $\Sigma$ S.S & $M \Sigma$ S.S & F calculated & F Table \\
\hline Treatments & 3 & 3290.65 & 1096.88 & $\mathbf{6 4 5 . 2 2}^{* *}$ & $\mathbf{3 . 4 5}_{(\mathbf{p}<0.01)}$ \\
\hline E.R & 12 & 20.44 & 1.70 & & $\left.5_{(\mathbf{9 5}}<0.05\right)$ \\
\hline Total & 15 & 3311.09 & & & \\
\hline
\end{tabular}


Table 9: General farmers average yields of potatoes $(t / h a)$

\begin{tabular}{|l|l|}
\hline Farmer \&Treatments & Yield \\
\hline A & $($ No farmer agreed to apply $)=0.0$ \\
\hline B & 38.70 \\
\hline C & 12.32 \\
\hline D & 35.15 \\
\hline
\end{tabular}

\section{CONCLUSION}

Regarding, the actual needs of the potatoes crop for NPK fertilization and although the high yields recorded from farmers fertilization practices (Treatment B and D), we thought that yet the fertilization efficiency is still low because of the use of a very high fertilization rates and more irrigation water than needed by the crop, where much of the applied fertilizers and water subject to leaching. At the present, with the studied fertilizers combinations. No clear statements could be given. It's just a primary investigation. We recommend that:

$1 /$ further research in organic and minerals fertilization of this crop with special attention directed towards $\mathrm{K}, \mathrm{P}, \mathrm{Ca}, \mathrm{Mg}$ and micro nutrients more closely are needed, to have the best way to fertilize this crop for high yielding and quality.

2/ recommendations should be as a technical package for fertilization, irrigation and other agronomic practices.

\section{REFERENCES}

Badawi, H. S. (1992).Cotton Nutrition in Gezira Vertisols, M.Sc. Thesis, U. Kart. Sudan.1992.

Fagera, N.K., V.C.Baligar and C.A. Jones.(1997). Growth and Mineral Nutrition of Field Crops. 2 nd Edition. Marcel Dekker Inc., New York.

Grewal, J.S., K.C. Sud and R.C.Sharma (1991).Soil and plant tests for potato. Technical Bulletin No.31.Centeral Potato Research Institute, Shimla, India. 
Hassan, Ahmed Abdel-Moneim (1999). Potato production. Arab House for Publishing and Distribution, Cairo.

Kidder, G., E.A. Hanlon, and G .J. H0chmuth. (1989).IFAS standardized fertilization recommendations for vegetables crops.Fla.Croop.Ext.Serv.Spec.Ser.SS-SOS-907.

Marschner, H. (1995). Mineral nutrition of Higher Plants. 2nd Ed. Academic Press, London.

Pearson, D., (1970). The chemical Analysis of Foods. J. \& A. Churchill, 104 , Gl. Place, Lon.

Perrenoud, S. (1993). Fertilization for High Yield Potato. IPI Bulletin 8. $2^{\text {nd }}$ Edition. International Potash Institute, Basel, Switzerland.

Rhue, R. D., D. R. Hensel. , T. L. Yuan and W. K. Robertson. (1981). Response of potatoes to soil and fertilizer phosphorus in northeast Florida .Soil Crop Sci. Soc.Fla. Proc. 40:58-61.

Sharma, U. C. and Arora, B. R. (1989). Critical nutrient ranges for potassium in potato leaves and petioles. J. of Hort. Sci. v. 64, p. 4751.

Sharma, R. C., S. P. Trehan, S. K. Roy and Kumar. (1999). Nutrient management in potato. Indian Farming 49: 52-54.

Singh, J. P. and S. P. Trehan.(1998). Balanced fertilization to increase the yield of potato. In: Proceedings of the IPI-PRII-PAU Workshop on: Balanced fertilization in Punjab Agriculture, held at Punjab Agricultural University, Ludhiana. India, 15-16 December 1997. pp. 129-139.

Westermann, D.H., T.A. Tindall, D.W. James and R.L. Hurst. (1994).Nitrogen and potassium fertilization of potatoes: yield and specific gravity. Am. Potato J. 71: 417-431. 


\section{الملخص العربيى}

\section{تأثيرالتسميد على محتوى اوراق ومحصول البطاطس المروية}

حمدى بدوى*، اشرف سويدان* ونور الدين بلج**

هذه الدر اسة مأخوذة من تجارب حقلية أجريت في منطقة المرازيق جنوب شرق مطار طر ابلس

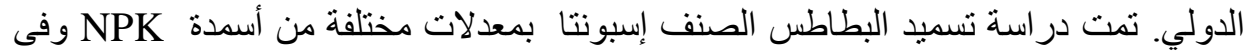
أزمنة مختلفة وتأثير ذلك على محتوى أوراق البطاطس من العناصر المغذية ومستوى

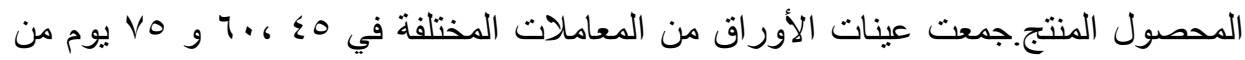
تاريخ الإنبات.تم تحليل العينات النباتية للنيتروجين ، البوتاسيوم ، الكالسيوم و الماغنسيوم.

أوضحت النتائج أن محتوى الأوراق من النيتروجين عند حد النقص في أواخر الموسم (0 ليوم

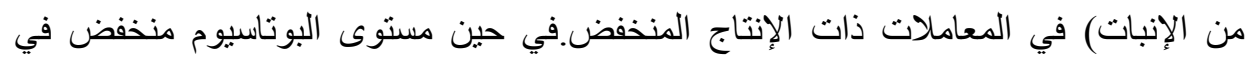
المعاملات ذات الإنتاج العالي في أو اخر الموسم ولكن في الحد الكافي .نركيز الكالسيوم وجد في

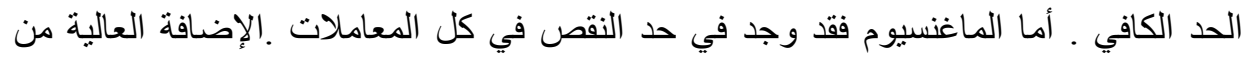

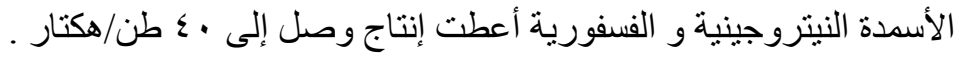

